\title{
Taking EU Equality Law to the Next Level: in Search of Coherence
}

\author{
Dr Sara Benedi Lahuerta ${ }^{1}$ \\ Accepted for publication in the European Labour Law Journal as part of a Special Issue on Future Directions in \\ EU Labour Law (Jeremias Prassl, ed)
}

\begin{abstract}
EU employment equality law is the product of fifty years of law-making. This gradual evolution has led to fragmentation and differences in the protection afforded to protected grounds, often referred to as a 'hierarchy of discrimination grounds'. This paper argues that human dignity is one of the underlying values of EU equality law, and therefore, the existence of a 'hierarchy' is not deliberate, but rather the accidental product of progressive waves of legislative evolution. It is thus submitted that EU equality law should keep evolving to achieve a coherent approach to address discrimination. This requires a legal framework that is logical and consistent and aligned with international human rights instruments. On this basis, the paper discusses two proposals to improve the coherence of EU employment equality law, namely, explicitly prohibiting gender identity discrimination and embracing reasonable accommodation for religious practices through a broad interpretation of the concept of indirect discrimination.
\end{abstract}

Key words: discrimination; coherence; gender identity; religion; reasonable accommodation

\section{Introduction}

In the last fifty years, EU equality law has come a long way. Its origins can be traced back to the right to equal pay between men and women, initially conceived as a market right to prevent unfair competition. ${ }^{2}$ However, from the 1970 s equal treatment started to be perceived as a social right, which was progressively developed through secondary legislation. ${ }^{3}$ After the Treaty of Amsterdam introduced what is now article 19 TFEU (ex article 13 EC), two directives expanded the prohibition of employment discrimination to five completely new protected grounds, ie race or ethnic origin, religion, disability, age and sexual orientation. ${ }^{4}$ These were followed by additional secondary legislation, such as the Recast Directive in $2006,{ }^{5}$ in what seemed to be a never-ending process of enacting new and revised equality legislation, until the 2008 financial crisis provoked a change in policy and legislative priorities.

This progressive evolution has led to a fragmented legal framework, where different discrimination grounds are covered by different Directives. Whilst the definitions of the prohibited forms of discrimination have been harmonised, differences remain between the levels of protection afforded for different grounds. A wealth of academic commentators have criticized these divergences for creating a 'hierarchy of equalities', ${ }^{6}$ whilst others have sought to

\footnotetext{
${ }^{1}$ Lecturer in Employment Law, Law School and Work Futures Research Centre, University of Southampton.

${ }^{2}$ But cf with the CJEU's interpretation of the purpose of former article 117 EEC in Case 43/75 Defrenne $v$ Sabena ECLI:EU:C:1976:56, paras 11-12.

3 eg Council Directive (EC) 76/207 on the implementation of the principle of equal treatment for men and women as regards access to employment, vocation training and promotion and working conditions OJ 1976 L39/40.

${ }^{4}$ Council Directives (EC) 2000/43 implementing the principle of equal treatment between persons irrespective of racial or ethnic origin OJ 2000 L 180/22 (RED) and 2000/78 establishing a general framework for equal treatment in employment and occupation OJ 2000 L 303/16 (EED).

${ }^{5}$ Parliament and Council (EC) Directive 2006/54 on the implementation of the principle of equal opportunities and equal treatment of men and women in matters of employment and occupation (recast) OJ 2006 L204/23.

${ }^{6}$ eg S Fredman, 'Equality: A New Generation?' (2001) 30 ILJ 145; L Waddington and M Bell, 'More Equal than Others: Distinguishing European Union Equality Directives' (2001) 38 CMLRev 587; E Howard, 'The case for a considered hierarchy of discrimination grounds in EU law' (2006) 13 MJ 445.
} 
understand whether there might be reasons for providing different levels of protection for different grounds. ${ }^{7}$ This paper builds on that literature to consider whether more coherence is needed in the field of EU employment equality law and, if so, how it could be achieved.

On the other hand, having in mind that enforcement of EU equality law at national level remains problematic, some argue that, in the next years, the EU focus should not be on generating more legislation and institutions, but rather on improving the existing ones. ${ }^{8}$ Whilst recognising that better enforcement mechanisms are needed, this paper contends that more substantive coherence in the protection afforded to different discrimination grounds is also required, even if this entails enacting new legislation, particularly now that the economic crisis seems to be coming to an end. ${ }^{9}$ In this context, the central question that the paper addresses is: How should EU employment equality law evolve to be more coherent? In a European Union with increasingly ageing population, where the gender pay gap is still $20 \%,{ }^{10}$ and where aversion to ethnic and religious diversity seems to be growing, ${ }^{11}$ addressing these challenges is crucial.

In this context, the term 'coherence' is used to refer to a legal framework which is 'logical and consistent ${ }^{12}$ in itself and that is aligned with the foundations of EU equality law. In addition, following Schwellnus, I refer to two dimensions of 'coherence': internal coherence, when proposals for change would bring EU rules in line with pre-existing EU legislation and policies; external coherence, when proposals for change would bring EU rules in line with international human rights instruments. ${ }^{13}$ Both dimensions are considered as potential reasons for introducing changes to EU equality law.

The paper starts by briefly recalling the evolution of EU equality law (section 2). It then analyses the theoretical foundations for improving the coherence of EU equality law (section 3) and finally suggests two avenues to improve substantive coherence (section 4), namely, expressly prohibiting gender identity discrimination (sub-section 4(a)) and extending the duty of reasonable accommodation to religion or belief (sub-section 4(b)).

\section{The piecemeal evolution of EU equality law: from a market right to a fundamental right}

This section briefly revisits the deep transformation that EU equality law has undergone in the last 50 years, with an emphasis on its progressive evolution from a market right to a social and then to a fundamental right.

The first expression of the right to equal treatment at EU level was the principle of equal pay, established in article $119 \mathrm{EEC}$ (current article $157 \mathrm{TFEU}$ ). The only other treaty provision which dealt with equality was article 6 EEC (current article 18 TFEU), which prohibited discrimination on grounds of nationality. Both articles had a clear market rationale: article 119

\footnotetext{
7 eg D Schiek, “A new framework on equal treatment of persons in EC Law?" (2002) 8 ELJ 290, 308; Bell and Waddington, 'Reflecting on inequalities in European equality law' (2003) 6 ELRev 349, 355-358.

${ }^{8} \mathrm{~T}$ E Givens and R E Case, Legislating equality: The politics of antidiscrimination policy in Europe (OUP 2014) 130.

${ }^{9}$ European Central Bank, Economic Bulletin, Issue 7/2015, 3.

${ }^{10}$ EIGE, Gender Equality Index 2015 - Measuring gender equality in the European Union 2005-2012: Report (EIGE 2015$) 37$.

${ }^{11}$ See eg H E Busemann, 'Merkel, heckled on visit to refugees, says no to xenophobia' (26 August 2015) Reuters $<$ http://www.reuters.com/article/2015/08/26/us-europe-migrants-merkel-

idUSKCN0QV1LL20150826\#TFThhkkEcxQdc8YZ.97> accessed 20 November 2015; 'New report highlights "sharp rise" in anti-Muslim attacks and 'environment of hate' in Britain' The Independent (18 November 2015).

12 A Stevenson (ed), Oxford dictionary of English (3 ${ }^{\text {rd }}$ ed, OUP 2010).

13 G Schwellnus, 'Reasons for constitutionalization: non-discrimination, minority rights and social rights in the Convention on the EU Charter of Fundamental Rights', in B Rittberger and F Schimmelfenning (eds), The Constitutionalization of the European Union (Routledge 2007) 118, 119-120.
} 
sought to prevent unfair competition; ${ }^{14}$ article 6 was necessary to ensure the free movement of persons within the common market. ${ }^{15}$ However, article 119 EEC acquired more social prominence thanks to the 'judicial activism' of the CJEU, which recognised its direct effect ${ }^{16}$ and established that it also had social objectives. ${ }^{17}$

In the 1970s, however, the Community realised that the common market needed a 'human face', and the development of social policies was perceived as a valid means to achieve that. ${ }^{18}$ Hence, following the adoption of the Social Action Programme, ${ }^{19}$ article 119 EEC was supplemented with a 'corpus' ${ }^{20}$ of secondary legislation which went far beyond equal pay, such as Directive $76 / 207 /$ EEC on equal treatment for men and women in employment. ${ }^{21}$

In a third stage, the Community started to recognise equal treatment not only as a social right, but also as a fundamental right. The 1989 Community Charter on fundamental social rights for workers ${ }^{22}$ established the right to equal treatment between men and women in article 16, which was implemented ${ }^{23}$ through secondary legislation, such as Directive $97 / 80 / \mathrm{EC}$ on the burden of proof in sex discrimination cases. ${ }^{24}$

Following the insertion of the citizenship provisions in the Maastricht Treaty, the CJEU expanded the scope of protection against nationality discrimination to cover, in some instances, citizens who were not economically active. ${ }^{25}$ Nationality discrimination seemed thus 'to be in a process of transition from a free movement right to a fundamental right ${ }^{26}$ And this process was arguably extended more broadly to the right to equal treatment as a result of the insertion of article 13 EC (current article 19 TFEU) in the 1997 Amsterdam Treaty, enabling the Community to adopt non-discrimination legislation on the grounds of sex, racial or ethnic origin, religion or belief, disability, age or sexual orientation. ${ }^{27}$ This was developed through Directive 43/2000 prohibiting racial discrimination within and outside employment ('Race Equality Directive', RED), and Directive $78 / 2000$ prohibiting discrimination on grounds of religion or belief, disability, age or sexual orientation in employment (only) ('Employment Equality Directive', EED). These directives were praised, inter alia, for expanding the scope of

${ }^{14}$ Defrenne (n 2), para 9. See also A Christensen, 'Structural Aspects of Anti-Discriminatory Legislation and Processes of Normative Change', in A Numhauser-Henning (ed), Legal Perspectives on Equal Treatment and Non-Discrimination (Kluwer 2001) 52.

${ }^{15}$ S O'Leary, 'Free Movement of Persons and Services', in P Craig and G De Búrca (eds), The Evolution of EU Law (2 ${ }^{\text {nd }}$ ed, OUP 2011) 499.

${ }_{16}$ Case 80/70 Defrenne v Belgian State ECLI:EU:C:1971:55.

${ }^{17}$ Namely, preventing unfair competition between companies established in different MS, many of which had not yet passed equal pay laws, see Defrenne (n 2) para 10.

18 P Teague, 'Labour Market Governance in the New Europe' (1994) 16 Employee Relations 5, 6.

19 [1974] OJ C12.

${ }^{20}$ M Bell, 'The Principle of Equal Treatment: Widening and Deepening', in P Craig and G De Búrca (eds), The evolution of EU law (OUP 2011) 611, 615.

${ }^{21}$ This Directive had to be passed relying on the flexibility clause of article 235 EEC (current article 352 TFEU); see further P Watson, EU Social and Employment Law. Policy and Practice in an Enlarged Europe (OUP 2009) 48-49.

22 Social Europe 1/90, 46-50 <http://www.eesc.europa.eu/resources/docs/community-charter--en.pdf> accessed 20 November 2015.

23 On implementation difficulties see Watson (n 21) 56-57.

24 OJ L 14.

${ }^{25}$ See eg Cases C-85/96 Martinez Sala v Freistaat Bayern ECLI:EU:C:1998:217, paras 61-64; C-184/99 Grzelczylk ECLI:EU:C:2001:458, paras 31-35; C-224/98 D'Hoop v Office national de l'emploi ECLI:EU:C:2002:432, paras 25-28. See further M Poiares Maduro, 'Striking the Elusive Balance Between Economic Freedom and Social Rights in the EU', in P Alston, M Bustelo and J Heenan (eds), The EU and Human Rights (OUP 1999) 449, 456-457.

${ }^{26}$ Bell, Anti-Discrimination Law and the European Union (OUP 2002) 39.

27 See A Masselot, 'The State of Gender Equality Law in the European Union’ (2007) 13 ELJ 152. 
EU equality law beyond gender and nationality discrimination. However, they were also criticized for creating a 'hierarchy' of discrimination grounds, ${ }^{28}$ where race was at the top, ${ }^{29}$ given the RED's wider material scope, its limited exceptions, and the duty to set up national equality bodies (not required for the other grounds). The EED also introduced a special feature for disability discrimination: the employer's duty of reasonable accommodation. ${ }^{30}$ Whilst protection against gender discrimination was initially left behind, it was quickly brought in line with that available for race with the adoption of Directive 2002/73, followed by the Recast Directive 2006/54, which harmonised employment gender equality law. On the other hand, age was considered to be at the bottom of the hierarchy, ${ }^{31}$ but it could be argued that the ground which was really at the bottom was -and still is- gender reassignment. ${ }^{32}$

Equal treatment's status as a fundamental right within EU law was confirmed, finally, with the insertion of article 21(1) in the EU Charter of Fundamental Rights, adopted in $2000 .{ }^{33}$ Although the Charter only applies in the implementation of EU law by EU institutions and MS, ${ }^{34}$ and it cannot be utilized to extend the competences of the Union, ${ }^{35}$ it signifies in a more visible and vigorous manner the EU's commitment towards protecting equal treatment as a fundamental right. ${ }^{36}$

Overall, whilst the right to equal treatment seems to have consolidated its fundamental right status within EU law, and an increasing number of academics are referring to the constitutionalization of the EU right to equal treatment, ${ }^{37}$ this piecemeal evolution has left some inconsistencies behind, which cast doubts on the robustness of EU law's protection in this field. In fact, in the same way that EU citizenship is still perceived by some as a market right rather than as the fundamental status of Union citizens, ${ }^{38}$ these inconsistencies in the right to equal treatment could be a sign that, despite its formal consolidation as a fundamental right, it is still, in practice, more a market right than a fundamental right. Addressing this lack of coherence seems essential to strengthen the EU right to equal treatment as a constitutional right.

\section{The theoretical foundations of the need for coherence: dignity and the EU concept of equality}

As discussed in section 2, EU equality directives are the product of a progressive development, which has led to piecemeal legislation and inconsistencies. It thus seems logical to reflect on

\footnotetext{
28 eg Waddington and Bell (n 6) 587; E Howard, 'The case for a considered hierarchy of discrimination grounds in EU law' (2006) 13 MJ 445.

${ }^{29}$ Waddington and Bell, ibid 590.

${ }^{30}$ Art 5 EED; see also L Waddington and A Hendriks, 'The Expanding Concept of Employment Discrimination in Europe: From Direct and Indirect Discrimination to Reasonable Accommodation Discrimination' (2002) 18 International Journal of Comparative Labour Law and Industrial Relations 403.

31 ibid 610 .

${ }^{32}$ See section (4)(a).

${ }^{33}$ [2000] OJ C364/1. Note that the Charter also contains other more specific rights which are connected to equal treatment, namely arts 20, 22-26.

${ }^{34}$ Art 51(1) Charter.

35 Art 6(1) TEU and art 51(2) Charter.

36 P Craig and G De Búrca, EU Law. Text, Cases and Materials (6 $6^{\text {th }}$ ed, OUP 2015) 396.

37 See eg A Morris, 'Constitutionalising Equality in the European Union: Tolerance and Hierarchies' (2005) 8 International Journal of Discrimination and the Law 33; M Bell, 'Constitutionalization and EU Employment Law' in H-W Micklitz (ed), Constitutionalization of European private law (OUP 2014); C O’Cinneide, 'The Constitutionalization of Equality within the EU Legal Order. Sexual Orientation as a Testing Ground' (2015) 22 MJ 370.

38 See N N Shuibhne, 'The Resilience of EU Market Citizenship' (2010) 47 CMLRev 1597, 1598, 1608-1609.
} 
the different levels of protection afforded for different discrimination grounds to establish whether they are random and undesired, or on the contrary, they are based on sound motives.

Some authors have suggested that the divergences between EU equality directives and the 'hierarchy' between EU equality grounds was not deliberately introduced, but rather the result of 'political pragmatism'. ${ }^{39}$ For instance, Waddington and Bell explain these divergences on the basis of the (lack of) familiarity of some MS with novel protected grounds, differences in the perceived levels of disadvantage suffered by target groups, varying levels of pressure exerted by lobby groups, and hidden secondary goals linked to some of the grounds. ${ }^{40}$ Remarkably, all these justifications are circumstantial: they are not based on sound theoretical differences between the grounds, but rather on contingent considerations.

Besides, a number of commentators have contended that all discrimination grounds should be afforded the same level of protection because 'prejudice is rarely limited to a specific category of persons ${ }^{41}$ and the protected grounds, whether they are biologically determined, socially established or personally chosen, ${ }^{42}$ are part of a person's 'inherent identity'. ${ }^{43}$ However, arguing that all grounds should be treated alike may overlook that different discrimination grounds may require different approaches to achieve substantive equality. ${ }^{44}$ For instance, different protected grounds may demand different promotion techniques due to the number of people affected and to economic and social considerations ${ }^{45}$ Furthermore, individuals bearing some protected characteristics, such as the disabled, older persons, pregnant women, and some religious minorities, may temporarily or permanently not be able to perform some tasks or have different 'availability or ability' to perform some work. ${ }^{46}$ These individuals may indeed require reasonable accommodation measures to perform certain jobs, whilst this is not normally the case for individuals suffering discrimination on grounds of race or sexual orientation.

For our purposes, the key question is whether having different levels of protection for different discrimination grounds suits the EU approach to equal treatment. The EU equality directives combine a formal and a substantive approach to equality: on the one hand, the definitions of direct and indirect discrimination are still based on comparisons; ${ }^{47}$ yet, on the other, they seek to put into effect the principle of equal treatment ${ }^{48}$ and, to achieve that, they establish, inter alia, an obligation to provide protection against victimisation ${ }^{49}$ or to the shift of the burden of proof, ${ }^{50}$ and they allow positive action. ${ }^{51}$ Whilst the CJEU has not always been consistent in interpreting

${ }^{39}$ Howard (n 6) 456.

${ }^{40}$ Bell and Waddington (n 7) 363-368; but cf Schiek (n 7) 308.

${ }^{41}$ Morris (n 37) 39.

42 cf Schiek (n 7) 308.

43 Morris (n 37) 40.

${ }^{44}$ P J Neuvonen, 'Inequality in equality' in the European Union equality directives: A friend or a foe of more systematized relationships between protected grounds?' (2015) 15 International Journal of Discrimination and the Law 222, 228.

45 Bell and Waddington (n 7) 355-358.

46 ibid, 359.

47 Arts 2(2) RED; 2(2) EED; 2(1)(a)-(b) Recast Directive.

${ }^{48}$ Arts 1 RED; 1 EED. Art 1 of the Recast Directive refers to ensuring 'the implementation' of the principle of equal treatment.

49 Arts 9 RED; 11 EED; 24 Recast Directive.

50 Arts 8 RED; 10 EED; 19 Recast Directive.

51 Arts 7 EED; 5 EED; 3 Recast Directive. 
the directives, ${ }^{52}$ it has implicitly relied on a substantive approach to equality to deliver landmark judgments, such as $P \vee S^{53}$ and Coleman. ${ }^{54}$

Substantive equality can be linked to the notion of dignity ${ }^{55}$ ie the idea that all human beings are worth equal respect and treatment regardless their personal characteristics. This connection between substantive equality and dignity has been emphasized in several jurisdictions, notably in Canada and South Africa. ${ }^{56}$ For instance, the Supreme Court of Canada has held that human dignity entails that every individual deserves equal 'concern, respect and consideration, ${ }^{57}$ and, whilst accepting that different individuals may have 'different needs, capacities and merits', ${ }^{58}$ it considers that 'our society cannot tolerate legislative distinctions that treat certain people as second class citizens' ${ }^{59}$

In EU law, the connection between dignity and equality may be less obvious, but it can also be traced, and it can be valuable to determine the level of protection to be afforded for each discrimination ground. For example, in $P \vee S$, the CJEU argued that gender reassignment discrimination fell within the scope of sex discrimination and could not be 'tolerated' because it 'would be tantamount, as regards such a person, to a failure to respect the dignity and freedom to which he or she is entitled, and which the Court has a duty to safeguard. ${ }^{60}$ Several Advocates General have also referred to dignity as an underlying value of the concept of equality. For instance, Poiares Maduro has noted that '[i]n order to determine what equality requires in any given case it is useful to recall the values underlying equality. These are buman dignity and personal autonomy ${ }^{61}{ }^{61}$ Cruz Villalón has also emphasized that

[ $\mathrm{t}$ ]he members of the political community, and by extension human beings, are equal in dignity, in the sense of the dignity of the individual, and this human dignity has been translated into an, initially limited, range of specific prohibitions on discrimination, with their formulation being closely linked to the evolving state of our constitutional culture. Today, Article 21 of the Charter, immediately following on from the general principle of equality laid down by Article 20, contains as many as fifteen unlawful grounds of discrimination. ${ }^{62}$

Cruz Villalón seems to imply that the EU's 'initially limited' protection against discrimination is indeed based on circumstantial reasons, and not on weighty theoretical motives, given that all human beings 'are equal in dignity' and that nowadays article 21 of the Charter contains fifteen expressly prohibited discrimination grounds -and, I would add, an open-ended prohibition,

\footnotetext{
52 See eg O’Cinneide (n 37) 383-394.

${ }^{53}$ Case C-13/94 P v S and Cornwall CC ECLI:EU:C:1996:170; see further C Barnard, 'P v S: Kite Flying or a New Constitutional Approach?' in A Dashwood and S O'Leary (eds), The Principle of Equal Treatment in EC Law (Sweet \& Maxwell 1997) 59.

54 Case C-303/06 Coleman v Attridge Law and Steve Law ECLI:EU:C:2008:415. The CJEU has also referred to 'substantive equality' explicitly, see eg Case C-537/07, Gomez-Limon Sanchez-Camacho v INSS, TGSS and Alcampo SA ECLI:EU:C:2009:462, fn 54; Case C-363/12, Z $\vee A$ Government department and The Board of management of a community school ECLI:EU:C:2014:159, para 10.

55 J Small and E Grant, 'Dignity, Discrimination, and Context: New Directions in South African and Canadian Human Rights Law' (2005) 6 Human Rights Review 25; S Fredman, Discrimination Law (2nd ed, OUP 2012) 19.

${ }^{56}$ Constitution of the Republic of South Africa 1996, s 1; see also Small and Grant, ibid; R O'Connell, 'The role of dignity in equality law: Lessons from Canada and South Africa' (2008) 6 International Journal of Constitutional Law 267.

${ }^{57}$ Andrews v Law Society of British Columbia [1989] 1 SCR 143, 171.

${ }^{58}$ Law v Canada (Minister of Employment and Immigration [1999] 1 SCR 497, 530.

59 ibid, 51.

${ }^{60} P \cup S$ (n 53) para 22.

${ }^{61}$ AG Opinion in Coleman (n 54) ECLI:EU:C:2008:61, para 8.

${ }^{62}$ AG Opinion in Case C-447/09 Prigge v Lufthansa ECLI:EU:C:2011:321, para 31.
} 
which can extend its application to additional grounds. Moreover, the link between EU equality and human dignity is also supported by the preamble and article 20 of the Charter, ${ }^{63}$ and by the EU prohibition of harassment, which requires that the unwanted conduct has 'the purpose or the effect of violating the dignity of a person'. ${ }^{64}$

This can indeed indicate that a hierarchy of discrimination grounds was never meant to exist in EU law. In fact, the Council has declared that 'the different forms of discrimination cannot be ranked: all are equally intolerable'. ${ }^{55}$ So in the same way that the current legal framework is the product of decades of evolution, it could be argued that it should keep evolving and improving to develop -in the words of the Commission- 'a coherent and integrated approach towards the fight against discrimination', whilst also 'recognising the specific challenges faced by different groups'. ${ }^{66}$ It thus seems justified to revise the EU legal framework to remove random inconsistencies in the level of protection afforded to different discrimination grounds, but taking into account substantive differences between the grounds, which may require different courses of action to address inequality.

\section{Two proposals to improve coherence}

In order to illustrate the proposed approach, the present section considers how to address two inconsistencies that arguably undermine the coherence of EU equality law: the lack of express binding protection for gender identity discrimination (sub-section a) and the fact that the duty of reasonable accommodation only applies to people with disabilities (sub-section b) ${ }^{67}$

\section{a. Gender reassignment: the Cinderella of discrimination grounds?}

Gender reassignment is the only discrimination ground which is deemed to be protected under EU law but is not explicitly outlawed in legislation. Since the ruling in $P v S^{68}$ in 1996, 'sex' discrimination has been interpreted as including gender reassignment discrimination. ${ }^{69}$ More recently, recital 3 of the Recast Directive established that 'the principle of equal treatment for men and women [...] also applies to discrimination arising from the gender reassignment of a person'. However, only eight MS have expressly prohibited gender reassignment discrimination. ${ }^{70}$ Whilst in some MS gender equality law is being interpreted as prohibiting gender reassignment discrimination, ${ }^{71}$ the lack of explicit legislation can arguably hinder the dissemination of the prohibition at social level. Indeed, legislation can have positive symbolic effects, particularly when it is accompanied by responsive policy measures and interaction with

\footnotetext{
${ }^{63}$ See also art 35 in connection with the rights of the elderly.

${ }^{64}$ Arts 2(3) RED, 2(3) EED, 2(1)(c) Recast Directive. See also G S Friedman and J Q Whitman, 'The European Transformation of Harassment Law: Discrimination versus Dignity' (2002) 9 Columbia Journal of European Law 241. ${ }^{65}$ Council (EC), Decision of 27 of November 2000 establishing a Community action programme to combat discrimination (2001 to 2006) [2000] OJ L 303/23.

${ }^{66}$ Commission (EC), Equality and Non-Discrimination in an Enlarged European Union', Green Paper (2004) 10.

${ }^{67}$ Whilst additional improvement proposals could have been made, due to space constraints, these two were chosen due to their salience.

${ }^{68} \mathrm{P} v S$ (n 53).

69 ibid paras 20-21. The CJEU has applied this principle in two other cases: Case C-117/01 K.B.v National Health Service Pensions Agency and Secretary of State for Health ECLI:EU:C:2004:7; Case C-423/04 Richards v Secretary of State for Work and Pensions ECLI:EU:C:2006:256.

${ }^{70}$ Namely, Belgium, Czech Republic, Greece, UK, Slovakia, Malta, Germany and Hungary. See Commission (EU), 'Report on the application of Directive 2006/54/EC of the European Parliament and of the Council of 5 July 2006 on the implementation of the principle of equal opportunities and equal treatment of men and women in matters of employment and occupation (recast)' $\operatorname{COM}(2013) 861$ final 5.

${ }^{71}$ In Denmark, Ireland, Spain, France, Cyprus, Austria and Croatia, ibid 5-6.
} 
target groups. ${ }^{72}$ The lack of an express prohibition of gender identity discrimination may thus have some bearing on the fact that $41 \%$ of respondents to an EU survey were not aware of laws prohibiting gender identity discrimination in employment, whereas the rate was lower for sexual orientation discrimination, ${ }^{73}$ which is explicitly outlawed at the EU level (and hence, also at the domestic level). What is more, data suggest that transgender people rarely report discrimination, not only because they are afraid of being identified and victimised, but also because they are unaware of their rights and how to exercise them. ${ }^{74}$

Besides contributing to the dissemination of rights, legislation can also have an 'expressive function' ${ }^{75}$ by recognising key social values, it can elevate them to a higher level and signpost a community's commitment to ensure that they are respected. Hence, the fact that $20 \mathrm{MS}$ do not explicitly outlaw gender reassignment may partly explain why, among LGTB people, transgender people are the ones who suffer higher levels of discrimination, both in access to employment $(30 \%)$ and in employment $(23 \%) .^{76}$

On the other hand, the three gender identity cases which have reached the CJEU so far concerned people who had undergone gender reassignment surgery, so it is unclear whether trans people who have not undergone reassignment or do not intend to are protected against discrimination. ${ }^{77}$ Furthermore, this interpretative solution is not entirely satisfactory because gender reassignment is only one particular aspect of the broad spectrum of discrimination on grounds of gender identity and gender expression'. ${ }^{78}$ Indeed, the term 'trans' is generally used to refer to people 'whose gender identity and/or gender expression differs from the sex assigned to them at birth', ${ }^{79}$ which includes, inter alia, people who live in their desired gender on a continuous basis without undergoing gender reassignment medical treatment and/or surgery, as well as people who occasionally cross-dress. ${ }^{80}$ Furthermore, many trans people do not understand gender in binary terms: they may see themselves as 'more than male and more than female', or as neither male nor female. ${ }^{81}$

Whether trans people decide to undergo gender reassignment or not, the origin of discriminatory conducts against them is always the same, ie the fact that their preferred gender identity differs -always or at some point- from the sex that they were physically given at birth, or as Bell puts it, the fact that their behaviour 'does not conform to social norms about genderappropriate conduct'. ${ }^{2}$ The broader concept of 'gender identity' is thus much more appropriate

\footnotetext{
72 W J Witteveen, 'Turning to communication in the study of legislation' in N Zeegers, W Witteveen and B Van Klink (eds), Social and Symbolic Effects of Legislation under the Rule of Law (Edwin Mellen 2005) 17, 30-31; see also R Schwitters, 'Symbols work', in Zeegers, Witteveen and Van Klink (ibid) 89, 91.

${ }^{73}$ FRA, European Union lesbian, gay, bisexual and transgender survey: Main results (EUPO 2014) 43-44.

${ }^{74}$ Equinet, Making Equality Legislation work for Trans People (Equinet 2010) 6-7.

75 Witteven (n 72) 31.

${ }^{76}$ FRA, European Union lesbian, gay, bisexual and transgender survey: Main results (EUPO 2014) 29.

${ }^{77} \mathrm{~S}$ Agius and C Tobler, Trans and intersex people. Discrimination on the grounds of sex, gender identity and gender expression (Human European Consultancy-MPG 2011) 43.

78 ibid.

${ }^{79}$ FRA, Being Trans in the European Union: Comparative analysis of EU LGBT survey data (EUPO 2014) 14.

${ }^{80}$ For a more comprehensive discussion of the meaning of 'trans people', see Agius and Tobler (n 77) 12-13.

81 V Baird, 'Transgender identities: like stars in the sky' in S Plous (ed), Understanding prejudice and discrimination (McGrawHill 2003) 415.

82 M Bell, 'Gender Identity and Sexual Orientation: Alternative Pathways in EU Equality Law' (2012) 60 American Journal of Comparative Law 127, 134.
} 
to cover the whole spectrum of situations which may give rise to discrimination against trans people. ${ }^{83}$

This concept is increasingly being used by international human rights bodies and has led to an upsurge in recommendations to expressly prohibit gender identity discrimination at national level. Already in 2006, the Yogyakarta Principles established that states should '[t]ake all necessary legislative, administrative and other measures to eliminate and prohibit discrimination on the basis of [...] gender identity' in employment. ${ }^{84}$ In 2009 the Committee on Economic, Social and Cultural Rights made clear that the term 'other status' in article 2(2) of the International Covenant on Civil and Political Rights includes gender identity. ${ }^{85}$ In 2012, the UN Office of the Human Rights Commissioner recommended to include gender identity as a discrimination ground. ${ }^{86}$ And more recently, the Parliamentary Assembly of the Council of Europe (PACE) called on member states to 'explicitly prohibit discrimination based on gender identity in national non-discrimination legislation and include the human rights situation of transgender people in the mandate of national human rights institutions, with an explicit reference to gender identity'. ${ }^{87}$ Within the EU, the Fundamental Rights Agency has also recommended that EU law expressly forbids discrimination on grounds of gender identity. ${ }^{88}$

It is therefore clear that there is an emerging international trend which considers gender identity as a 'suspect' ground ${ }^{89}$ that should be explicitly included in anti-discrimination legislation. From a social perspective, the Eurobarometer also shows a growing acceptance of diverse gender identities: in 2015, 53\% of respondents were comfortable or indifferent with having a transgender or transsexual person in the highest political office (compared to $43 \%$ in 2012) and $67 \%$ would be comfortable with or indifferent to working with a transgender or transsexual person. $^{90}$

An EU which is truly committed to respect dignity, equality and human rights ${ }^{91}$ and aspires to become a member of the $\mathrm{ECHR}^{92}$ should embrace the growing international and social acceptance of diverse gender identities by going beyond the uncertain case-law based protection. Indeed, the real scope of the CJEU interpretation in $P v S$ and subsequent cases is unclear. Does it only apply to gender reassignment or can it also apply more broadly to gender identity discrimination? Within the academic literature there is disagreement. For instance, Bell maintains that, given that the CJEU's reasoning in $P v S$ was partly based on the need 'to respect

\footnotetext{
${ }^{83}$ See the definition in Yogyakarta Principles on the Application of International Human Rights Law in relation to Sexual Orientation and Gender Identity <http://yogyakartaprinciples.org/> accessed 20 September 2015.

$84 \mathrm{ibid}$, principle 12.

${ }^{85}$ Committee on Economic, Social and Cultural Rights, General Comment No. 20, Non-Discrimination in Economic, Social and Cultural Rights U.N. Doc. E/C.12/GC/20 (2009), at 32.

${ }^{86}$ UNHRHC, 'Born free and equal. Sexual Orientation and Gender Identity in International Human Rights Law' (2012) <http://www.ohchr.org/Documents/Publications/BornFreeAndEqualLowRes.pdf> accessed 17 September 2015, p. 13; see also Resolutions 17/19 and 27/32 Human rights, sexual orientation and gender identity, UN docs $\mathrm{A} / \mathrm{HRC} / \mathrm{RES} / 17 / 19$ and A/HRC/RES/27/32.

87 PACE, Resolution 2048 (2015) Discrimination against transgender people in Europe, adopted on 22 April 2015 (15th Sitting), at 6.1.1 (my italics).

88 FRA, 'LGBT persons' experiences of discrimination and hate crime in the EU and Croatia' <http://fra.europa.eu/sites/default/files/eu-lgbt-survey-factsheet_en.pdf> accessed 16 September 2015, 2.

89 On this concept see J Gerards, 'Discrimination Grounds' in D Schiek, L Waddington and M Bell (eds), Cases, Materials and Text on National, Supranational and International Non-Discrimination Law (Hart 2007) 33, 35-36. See also Howard, who has argued that 'suspectness' could justify whether a discrimination ground is afforded more or less protection (n 6) 458-460.

90 Special Eurobarometer 437. Discrimination in the EU in 2015 (Commission (EU) 2015) 61, 63.

${ }^{1}$ Art 2 TEU. See also art 8 TFEU.

92 Art 6(2) TEU.
} 
the freedom and dignity' of the individual, ${ }^{93}$ it remains possible that gender equality law can offer an effective vehicle for protection from gender identity discrimination'. ${ }^{94}$ In contrast, Skidmore argues that the CJEU ruling in $P v S$ is based on 'the idea that sex can and should be categorized' and that '[i]t does not yet open up the space for a continuum of sex and a spectrum of genders', ${ }^{95}$ which certainly clashes with the idea of gender identity. In this context, it is submitted that the best way to address this uncertainty and to achieve external coherence with the growing international accord is to expressly prohibit gender identity discrimination in legislation.

On a more pragmatic level, in the same way that differences in legislation on equal pay between men and women could have given rise to social dumping between MS in the 1950s, differences in protection against gender identity discrimination can also have negative consequences for the functioning of the internal market. Of course, women largely outnumber trans people, but there could be ' 1.5 million people in the EU who do not fully identify with the sex they were assigned at birth, ${ }^{96}$ which is still a significant figure.

Nevertheless, the lack of an obvious legal basis could be an obstacle to introduce an explicit prohibition of gender identity discrimination at EU level. Article 19 TFEU, which was the legal base used to enact the RED and the EED, contains a closed list of grounds which includes sex and sexual orientation, but not gender identity. It could be argued that the term 'sex' could be interpreted as including 'gender identity'. The CJEU stated in $P v S$ that gender reassignment discrimination 'is based, essentially if not exclusively, on the sex of the person concerned'. ${ }^{97}$ With this in mind, and considering that the CJEU has so far interpreted the term 'sex' as including gender reassignment, the term 'sex' in article 19 could perhaps be stretched to include 'gender identity'. However, this claim is likely to be controversial -especially from the perspective of MS - and could potentially lead to legal basis disputes. ${ }^{98}$

The legal basis hurdle could perhaps be overcome more straightforwardly through the use of the general legal basis in article 352 TFEU. ${ }^{99}$ This provision was already used in the past to enact sex equality legislation (eg Directive 76/207/EEC) when there was not a specific legal basis, and it could arguably be used again in this context. However, as for article 19 TFEU, the requirement of unanimity at the Council sets a high threshold that would require a strong political will on the part of MS. In spite of this, Schwellnus claims that achieving external coherence tends to be a very strong argument for introducing legislative changes contributing to the constitutionalization of EU equality law. ${ }^{100}$ Hence, the above-mentioned emerging agreement on the need to outlaw gender identity discrimination expressly, together with a wide mobilisation of civil society groups, ${ }^{101}$ and the growing social acceptance of diverse gender

\footnotetext{
${ }^{93} \operatorname{PvS}(\mathrm{n} 53)$ para 22.

94 Bell (n 82) 138.

95 P Skidmore, 'Can Transsexuals Suffer Sex Discrimination?’ (1997) 19 Journal of Social Welfare and Family Law 105, 109.

${ }^{96}$ Amnesty International, The State Decides Who I Am. Lack of Recognition for Transgender People (Amnesty International 1014) 11, relying on G J Gates, How many people are Lesbian, Gay, Bisexual and Transgender? (Williams Institute 2011) <http://williamsinstitute.law.ucla.edu/wp-content/uploads/Gates-How-Many-People-LGBT-Apr-2011.pdf> accessed 22 November 2015.

${ }^{97}$ para 21.

98 See eg the dispute regarding article 114 TFEU in Case C-376/98 Germany $v$ Parliament and Council ECLI:EU:C:2000:544.

99 Agius and Tobler (n 77) 32.

100 Schwellnus (n 13) 124, 133.

101 On the role of civil society organisations see eg I Solanke, Making anti-racial discrimination law: a comparative history of social action and anti-racial discrimination law (Routledge 2009).
} 
identities, could potentially contribute to build momentum to explicitly prohibit gender identity discrimination at EU level.

\section{b. Reasonable accommodation for religion or belief}

A second aspect which arguably undermines the internal coherence of EU equality law is the limited availability of the duty of reasonable accommodation. Article 5 of the EED requires employers to 'take appropriate measures, where needed in a particular case, to enable a person with a disability to have access to, participate in, or advance in employment, or to undergo training, unless such measures would impose a disproportionate burden on the employer'.

Whilst this duty, as such, is only expressly recognised as a tool to promote equal opportunities for the disabled, there is a similar -although not identical- ${ }^{102}$ EU law duty to accommodate working conditions for women who are pregnant or are breastfeeding, if the normal working conditions would entail risks for their health and safety. ${ }^{103}$

In other jurisdictions, however, the duty to accommodate also applies to other protected characteristics, such as religion in both the US and Canada, and in addition, in Canada, gender, national origin and age are also covered. On this basis, the EU could consider extending the duty to accommodate to other protected grounds, namely age and religion. For instance, Bell and Waddington argue that:

[EU] law establishes an obligation on employers to accommodate the specific needs of women, with regard to maternity, and people with disabilities, but makes no effort to provide similar rights to followers of (minority) religions or younger or older workers. This is in spite of the fact that age and religious belief, like pregnancy and disability, can sometimes affect the availability or ability to perform work. This inconsistency is further highlighted by the fact that the reasonable accommodation requirement covers religious followers in the United States, and has an even broader scope in Canada. ${ }^{104}$

For reasons of space, however, this section only focuses on the possibility of extending reasonable accommodation to religious practices. ${ }^{105}$

Nonetheless, importing the North-American approach towards religious accommodation to Europe may not be straightforward. For instance, in Canada, and particularly in Québec, extensive media coverage of a large number of religious accommodation cases in 2006-07 fed a general sentiment that accommodation was illegitimate or a form of threat to Québec society's values'. ${ }^{106}$ However, this led to extensive research and consultation by an advisory Commission, which then published a report calling for 'reconciliation'. ${ }^{107}$

Furthermore, in practice, it could be difficult to reach a unanimous agreement at the Council to amend the EED to introduce a religious accommodation duty. For instance, France would be likely to oppose such amendment to protect the constitutional principle of 'secularism', one

\footnotetext{
102 E Bribosia and I Rovire, Reasonable Accommodation beyond Disability in Europe? (EUPO 2013) 40-41.

103 Article 5(1) of Directive 92/85/EEC.

104 Bell and Waddington (n 7) 359.

${ }^{105}$ Note that Malcom Sargeant has argued that reasonable accommodation should also extend to age (see 'Older Workers and the Need for Reasonable Accommodation' (2008) 9 International Journal of Discrimination and the Law 168). The recent Commission Proposal 2015/0278 (COD) goes in that direction for access to certain goods and services (see eg recital 25).

$106 \mathrm{~T}$ Bouchard and C Taylor, Building the future, a time for reconciliation: Abridged report (Commission de consultation sur les pratiques d'accomodement reliées aux différences culturelles 2008).

107 ibid.
} 
of the core values of the French Republic. ${ }^{108}$ Under this principle, citizens who work in public schools are not allowed to wear visible religious symbols ${ }^{109}$ and those who work in 'public spaces' cannot wear clothing intended to conceal one's face (eg full-face covering veils). ${ }^{110}$

However, a reasonable accommodation duty could also be derived from the concept of indirect discrimination. ${ }^{111}$ Indeed, in Canada, the duty of reasonable accommodation initially arose out of the idea of substantive equality, which underpins the concept of 'indirect discrimination'. ${ }^{112}$

In Europe, the ECtHR has not expressly endorsed the concept of reasonable accommodation, ${ }^{113}$ but in Thlimmenos it clarified that:

The right not to be discriminated against in the enjoyment of the rights guaranteed under the Convention is also violated when States without an objective and reasonable justification fail to treat differently persons whose situations are significantly different. ${ }^{114}$

In other words, signatory states should accommodate ('treat differently') persons who have different needs ('whose situations are significantly different') unless there is an 'objective and reasonable justification' not do it. In the case at hand, a Jehovah's Witness who had successfully passed a competition to become a chartered accountant was not appointed to the post because he had been convicted for a serious crime due to his refusal -triggered by his religious beliefsto undertake Greek military service. The Grand Chamber considered that 'by failing to introduce appropriate exceptions to the rule barring persons convicted of a serious crime from the profession of chartered accountants' Greece had discriminated against the applicant. The requirement to introduce 'appropriate exceptions' unless there is an 'objective and reasonable justification' not to do it, can be interpreted as an implicit endorsement to the need to accommodate religious differences. The approach of the ECtHR essentially consists in analysing the 'reasonableness' of accommodation as part of the objective justification test which is inherent to indirect discrimination, ie whether the failure to treat the claimant differently pursued a legitimate aim and was proportionate. ${ }^{115}$

The Thlimmenos principle was further developed in a disability case, Glor v Swisstzerland, ${ }^{116}$ but the ECtHR has been more reluctant to apply it in religious discrimination cases. However, most of those cases (including the ones that pre-date Thlimmenos) concerned situations where the applicant was treated differently in the education sector ${ }^{117}$ or while working for a public

\footnotetext{
108 See Loi du 9 décembre 1905 concernant la séparation des Eglises et de l'Etat and Constitution du 4 octobre 1958, art 1 .

${ }^{109}$ Loi n ${ }^{\circ}$ 2004-228 du 15 mars 2004 encadrant, en application du principe de laïcité, le port de signes ou de tenues manifestant une appartenance religieuse dans les écoles, collèges et lycées publics.

${ }^{110}$ Loi n 2010-1192 du 11 octobre 2010 interdisant la dissimulation du visage dans l'espace public.

${ }^{111}$ L Waddington, 'Reasonable Accommodation' (2011) 36 NTM/NJCM-Bulletin 41, 49; K Alidadi, 'Reasonable accommodation for religion and belief: adding value to art. 9 ECHR and the EU's anti-discrimination approach in employment?' (2012) 37 ELRev 693, 707-710.

112 Ontario Human Rights Commission (O’Malley) v Simpsons-Sears [1985] 2 SCR 536.

${ }^{113}$ However, explicit references were made in Sessa v Italy, App No 28790/08 (ECtHR, 2 April 2012), Dissenting Opinion of Judges Tulkens, Popović and Keller, paras 9-15; Ebrabimian v France, App No 64846/11 (ECtHR, 26 November 2015), Partly Dissenting Opinion of Judge O’Leary.

114 Thlimmenos v Greece, App No 34369/97 (ECtHR, 6 April 2000) para 44.

115 As Tulkens, Popović and Keller have noted reasonable accommodation may 'constitute a less restrictive means of achieving the aim pursued' (n 113) para 9.

116 App No 13444/04 (ECtHR, 30 April 2009).

117 The interference being justified to protect vulnerable pupils and students from external religious pressures, see eg Dablab v Turkey, App No 42393/98 (ECtHR, 15 February 2001); Karaduman v Turkey, App No 41296/04 (ECtHR, 3 April 2007); Sabin v Turkey, App No 44774/98 (ECtHR, 10 November 2005); Dogru v France, App No 27058/05 (ECtHR, 4 March 2009). See also O’Leary (n 113).
} 
institution or in the access to a public service. For instance, $X \vee U K$ concerned the accommodation of working time of a Muslim working in a state school; ${ }^{118} \mathrm{SH}$ and $H V v$ Austria $^{119}$ and Sessa v Italy ${ }^{120}$ dealt with the national justice system (ie a hearing date clashing with a Jewish holiday); Kosteski related to a request of leave of absence by an employee of a public utility company to attend a Muslim public holiday; ${ }^{121}$ Ebrabimian concerned a contractual agent working in a public hospital. ${ }^{122}$ In contrast, in the Eweida case, where the differential treatment arose within a private company, the ECtHR found in favour of the applicant's right to have the company rules accommodated to her religious beliefs because there was 'no evidence of any encroachment on the interests of others'. ${ }^{123}$ Hence, in cases where the 'accommodation conflict' arises in the private sphere and the need to preserve state's neutrality is not at stake, the ECtHR seems to put a lower threshold to find that the rule is not justified, and therefore, the religious practice should be accommodated.

The CJEU has not expressly endorsed the principle of reasonable accommodation beyond disability, but it has defined the principle of equal treatment as requiring not only that identical situations be treated in the same manner, but also to treat differently different situations. ${ }^{124}$ In Thlimmenos the ECtHR relied on that same principle to argue that Greece should have accommodated the applicant's different situation, so the same logic could be followed by the CJEU in a case concerning an 'accommodation conflict'. In fact, in the Prais case the CJEU recognised that the accommodation of religious beliefs was 'desirable', although not required in casu. ${ }^{125}$ Prais was a Jewish applicant to an open competition who requested the date to be changed because it coincided with a Jewish holiday that prohibits travelling or writing. When her request was rejected she brought a claim arguing that such practice violated the EU Staff Regulations, which required that candidates are selected without distinction on grounds of, inter alia, religion. The Court recognised that ' $[\mathrm{i}] \mathrm{f}$ a candidate informs the appointing authority that religious reasons make certain dates impossible for him the appointing authority should $[\ldots]$ endeavour to avoid such dates', ${ }^{126}$ which resonates with the idea of reasonable accommodation. On the facts, however, given that the Council was not informed of the clash before fixing the date and that changing the date would have disadvantaged the other candidates, the Council was not bound to accommodate Prais' religious beliefs. ${ }^{127}$

Thanks to two pending preliminary references questioning the interpretation of the EED, Achbita ${ }^{128}$ and Bougnaoui, ${ }^{129}$ concerning two women dismissed for wearing the hijab at work in Belgium and France, respectively, the CJEU now has to address the issue of reasonable accommodation of religious diversity at the workplace. In these two cases, the hijab was in conflict with the respective companies' neutrality policies, the main difference between the two

\footnotetext{
118 App No 7215/75 (ECtHR, 12 March 1981).

119 App No 18960/91 (ECtHR, 13 January 1993).

120 App No 28790/08 (ECtHR, 3 April 2012).

${ }^{121}$ Kosteski v Former Yugoslavia Republic of Macedonia, App No 55170/00 (ECtHR, 13 April 2006).

122 Ebrabimian v France, App No 64846/11 (ECtHR, 26 November 2015).

${ }^{123}$ Eweida v UK, App Nos 48420/10, 59842/10, 51671/10 and 36516/10 (ECtHR, 15 January 2013), para 95. This also differentiated Eweida from the education cases (n 117), where the interests of pupils and students were arguably affected.

${ }^{124}$ Joint Cases T-18/89 and 24/89 Tagaras ECLI:EU:T:1991:8; Case T-10/93 A v Commission ECLI:EU:T:1994:39. In the context of the internal market, see also Case 13/63 Italian Republic v Commission ECLI:EU:C:1963:20.

125 Case 130/75 Prais v Council ECLI:EU:C:1976:142.

126 ibid, para 16.

127 ibid, paras 17-18.

${ }^{128}$ Case C-157/15 Achbita v G4S Secure Solutions NV (pending).

${ }^{129}$ Case C-188/15 Bougnaoui and AADD v Micropole Univers SA (pending).
} 
being that Bougnaoui had always worn the hijab and was only required not to wear it in the presence of clients, whereas Achbita started to wear it after having been employed for some time and was not allowed to wear it at all.

Whilst the questions asked by the national courts do not directly address a potential accommodation duty, the central issue in both claims is whether the neutrality rule is indirectly discriminatory for religious employees who feel compelled to wear visible religious symbols. This is a golden opportunity for the CJEU to position itself as regards the ECtHR's case law on religious dress, and in particular, to clarify whether, under the EU concept of indirect discrimination, there could be an obligation for employers to reasonably accommodate the needs of employees of certain religious faiths, unless the companies' rules pursue a legitimate aim and are proportionate.

In both cases, the legitimate aim seems to be quite similar to that adduced by British Airways in Eweida, ie the neutrality rule sought to protect the corporate image, particularly as regards its clients. In Eweida, however, there was no evidence of a clash with the rights of others, whereas in Bougnaoui a client seemed to be 'inconvenienced' by the headscarf. Yet, the mere fact that the client did not like watching her wearing the headscarf does not seem enough ground to argue that its 'rights and freedoms' were affected. ${ }^{130}$ As the ECtHR has pointed, 'democracy does not simply mean that the views of a majority must always prevail: a balance must be achieved which ensures the fair and proper treatment of people from minorities and avoids any abuse of a dominant position. ${ }^{131}$ Furthermore, the client's request that Bougnaoui should not wear the headscarf should not be interpreted as an occupational requirement ${ }^{132}$ because this exception is only applicable to 'very limited situations' 133 and not wearing a headscarf was not genuinely necessary and determining to successfully perform the substance of her job as a consultant engineer.

On the other hand, the fact that Achbita only started to wear the headscarf after some time does not seem a legitimate reason to dismiss her either, given that the freedom of religion includes the right 'to practise or not to practise a religion', and to manifest one's religion in private or in public. ${ }^{134}$ Arguably, then, one can start practising overtly some aspects of one's religion at a given point in time for the first time, and be protected under article 9 ECHR.

Considering that in both pending cases the arguments of the respondent companies do not seem sufficient to justify a restriction of the freedom of religion amounting to indirect discrimination, and in the light of the similarity between the ECtHR and the CJEU's definitions of equal treatment, it could be expected that the latter will follow the approach of the ECtHR in Thlimmenos and Eweida to recognise (at least implicitly) that a duty to reasonably accommodate differences is inherent to the concept of indirect discrimination.

\section{Conclusion}

This paper has demonstrated that the incremental evolution of EU equality law has led to some inconsistencies in the protection against employment discrimination. It is submitted that these inconsistencies are not based on normative grounds, but rather on circumstantial factors. Indeed, human dignity is one of the foundations of EU equality law, and that entails that all

\footnotetext{
130 Art 2(5) EED. Note also that derogations should be interpreted strictly (Case C-447/09 Prigge v Lufthansa ECLI:EU:C:2011:573, para 56).

131 Sabin (n 117) para 108.

132 Art 4(1) EED.

${ }^{133}$ Recital 23; see also Prigge (n 130) para 71.

134 Sabin (n 117) para 104-105.
} 
individuals are worth equal concern and respect. This supports the idea a hierarchy of discrimination grounds' was never meant to exist in EU law. Whilst recognizing that the protected grounds may have substantive features which justify the use of different tools to achieve equal treatment, some divergences between protected grounds undermine the internal coherence of EU equality law. Therefore, it seems desirable that the legal framework keeps evolving to address these inconsistencies.

A first aspect that undermines not only internal, but also, external coherence, is the fact that gender identity discrimination is not explicitly outlawed by EU law. Indeed, it is uncertain whether the current protection, derived from case law, goes beyond the mere prohibition of discrimination against individuals who have undergone or intend to undergo gender reassignment. It is thus submitted that the EU should follow the increasing number of international recommendations that draw attention to the need to prohibit gender identity discrimination. ${ }^{135}$

Secondly, whilst reasonable accommodation is a helpful tool to balance the needs of certain vulnerable groups and employers, at EU level it only applies to the disabled, and with a slightly different scope, to pregnant women. However, it could be useful not only for these groups, but also for ageing employees and religious minorities. Focusing on the latter, this paper has argued that the EU concept of indirect discrimination lends itself to an interpretation that could encompass a requirement to accommodate religious practices, unless the employer's reason not to do it is objectively justified. Whilst embracing reasonable accommodation of religious practices through this interpretative solution would not be quite the same as introducing a legal duty to accommodate, ${ }^{136}$ it could be a good and more practicable option that the CJEU now has the opportunity to consider in Achbita ${ }^{137}$ and Bougnaoui. ${ }^{138}$

Commentators are increasingly claiming that the fundamental right to equal treatment is being constitutionalized within EU law, but some of the current uncertainties ${ }^{139}$ and inconsistencies can undermine the robustness of protection at EU level and are against EU equality law foundations' on human dignity. Now that the economic crisis seems to be coming to an end, the EU and its MS should start putting back in the agenda policy areas that were left behind in the last years. The changes suggested in this paper point to some of the amendments that could be considered in the field of equality law. Whilst achieving consensus for some of the proposed initiatives may not be easy, if the $\mathrm{EU}$ is to be increasingly seen as not just an economic market, but rather as a 'constitutional market', ${ }^{140}$ or even more ambitiously, as a 'human rights actor', ${ }^{141}$ it should strive for improving substantive coherence within equality law.

\footnotetext{
135 The Commission has recently proposed new actions in this field, but they do not include expressly outlawing gender identity discrimination, see DG Justice, 'List of actions by the Commission to advance LGBTI equality' (7 December 2015) <http:/ / ec.europa.eu/justice/discrimination/files/lgbti_actionlist_en.pdf> accessed 1 March 2016. 136 Alidadi (n 111) paras 707-710.

137 Achbita (n 128).

138 Bougnaoui (n 129).

139 O'Cinneide (n 37) 382-384.

140 Shuibhne (n 43) 1608-1609.

${ }^{141}$ M Dawson, E Muir and M Claes, 'A Tool-box for Legal and Political Mobilisation in European Equality Law' in D Anagnostou (ed), Rights and Courts in Pursuit of Social Change. Legal Mobilisation in the Multi-Level European System (Hart 2014) 105.
} 